\title{
Antimicrobial Activities of the Henna Extract and Some Synthetic Naphthoquinones Derivatives
}

\author{
Nadjib Mohammed Rahmoun ${ }^{1, *}$, Zahia Boucherit-Atmani ${ }^{1}$, Mohammed Benabdallah ${ }^{2}$, Kebir Boucherit ${ }^{1}$, Didier \\ Villemin $^{3}$, Noureddine Choukchou-Braham² \\ ${ }^{1}$ Département de biologie, Faculté des Sciences, Tlemcen University, Algeria \\ ${ }^{2}$ Département de chimie, Faculté des Sciences, Tlemcen University, Algeria \\ ${ }^{3}$ ENSICAEN, UCBN, Caen University, Caen, France \\ *Corresponding author: nagrah113@ @otmail.com
}

Received December 28, 2012; Revised January 23, 2013; Accepted February 15, 2013

\begin{abstract}
Naphthoquinones are compounds widely distributed in the environment, both as natural products and as pharmaceutical agents. They have been the subject of much research due to their pharmacological activities. In this study, methanol extract of henna and a series of synthesized structural analogue of lawsone have been assessed for their antimicrobial activities. Methanol extract of henna and eight naphthoquinones derivatives were tested as potential antimicrobial agents against twelve bacteria and three Candida species using the agar disc diffusion and broth microdilution methods according to guidelines recommended by the Clinical and Laboratory Standards Institute.

Besides $2 \mathrm{~b}$ and $3 \mathrm{~b}$, methanol extract and all the synthesized compounds $1 \mathrm{a}, 2 \mathrm{a}, 1 \mathrm{~b}$ and $1 \mathrm{c}, 2 \mathrm{c}$ and $3 \mathrm{c}$ showed weakto-strong activity against at least one tested strain. However, the compounds $1 \mathrm{c}$ and $1 \mathrm{~b}$ were found to have the most effective activity against pathogenic bacteria and displayed an activity 8 to 64 fold higher than that othe structural analogue, lawsone. Their MICs ranged from 8-64 $\mu \mathrm{g} \mathrm{ml}^{-1}$. Henna extract was found to have an interesting activity. Our results indicate an effective in vitro activity of 1,4-naphthoquinone derivatives and suggest the benefits of further studies for its application in antibiotherapy.
\end{abstract}

Keywords: Antimicrobial activity, bioactives compounds, naphthoquinone, synthesis

\section{Introduction}

For thousands of years, medicine and natural products have been closely linked through the use of traditional medicines and natural drugs [1]. Natural products are typically secondary metabolites, produced by plants and microorganisms in response to external stimuli such as nutritional changes. They are widely recognized in the pharmaceutical industry for their remarkable structural diversity and wide range of pharmacological activities. Pharmacophores derived from natural products are well represented in lists of "privileged structures", which makes them excellent candidates for building blocks for biologically relevant chemical libraries [2].

Lawsonia inermis (Lynthraceae) commonly known as 'Henna' is a shrub frequently cultivated in the Middle East, along the African coast of the Mediterranean Sea and India. Besides its use in cosmetics for staining hands and as a hair dye, the leaves are used as a prophylactic against skin diseases. Its was reported to be useful in jaundice, enlargement of the spleen, calculus affliction, and skin diseases [3]. The extract of leaves of L. inermis has been shown to possess antimicrobial activity [4]. Ethanolic extract of the whole plant was found to have antifungal activity [5].

Quinones, and particularly naphthoquinones (NQs), are widespread among the secondary metabolites of henna plant. They can also be prepared synthetically and are widely produced by the chemical industry as organic dyes [6]. The interest of naphthoquinones is not restricted to the chemistry of dyes; a wide spectrum of biological activities is described for them, including antitumor, antibacterial, anti-inflammatory, antiparasitic, cytotoxic activities and others $[7,8,9]$. These biological activities have justified the large number of studies found in the literature aimed at the synthesis and evaluation of either natural quinones or their analogues as potential pharmacological agents [10]. In fact, some clinically antimicrobial drugs such as marinone debromomarinone [11], contain the quinone moiety as a relevant part of their structures.

Due to their complicated redox properties, quinones complexes have been of considerable interest for many years. Binding proprieties of quinones can be in three different oxidation states, viz. (i) quinone, (ii) it's oneelectron reduced form, semiquinone, and (iii) its two electron reduced form, catechol. Coordination complexes of quinones with different oxidation states reflect differences in their structural, magnetic and electrochemical properties [12]. The binding ability of quinones in different oxidation states allows them to play an important role in biological systems properties.

In most cases, the biological activity is related to the ability of quinones to accept one or two electrons to form highly reactive radical anion intermediates, which are responsible for the oxidative stress observed in the cells [10]. But there are several other mechanisms [13,14] attributed to quinonoid compounds such as DNA 
intercalation, alkylation, induction of DNA strand breaks or inhibition of special proteins or enzymes such as topoisomerases.

The aim of this study was to evaluate the in vitro antibacterial and antifungal activities of henna methanol extract and new naphthoquinones derivatives with free ketones $1 / 4$ function.

\section{Materials and Methods}

\subsection{Biological Materials}

The National Institute of Agronomic Research (NIAR, Adrar-Algeria) provided the proposed material for the study. It was identified and authenticated by us in collaboration with the service for plant authentication of NIAR and was submitted as $L$. inermis leaf. It was harvested in the area of Adrar in March 2008, dried and stored at room temperature in the dark. Plant extracts were prepared according to the method of Sharma (1990) [15] with minor modification. Extraction was carried out from the crushed dry leaves. Briefly, $25 \mathrm{~g}$ of powdered plant material were soaked in $100 \mathrm{~mL}$ of methanol. The mixture was stirred for $24 \mathrm{~h}$ and the extract was passed through Whatman filter paper No 1 (Whatman, UK). The filtrate was concentrated under vacuum on a rotary evaporator at low temperature $30^{\circ} \mathrm{C}$. The extracts were all stored at $4^{\circ} \mathrm{C}$ until further use.

\subsection{Chemistry}

A series of new molecules, 1a, 2a, 1b, 2b, 3b, 1c, 2c and $\mathbf{3 c}$, of substituted naphthoquinones, were synthesized under mild conditions "Green Chemistry" in the laboratory: Laboratoire de catalyse et synthèse en chimie organique, Département de Chimie, Faculté des Sciences, BP119, Tlemcen University, Tlemcen, Algeria.

Lawsone (L) and 2,3-dichloro-1,4-naphthoquinone (a) were purchased from Sigma-Aldrich and were used without further purification. All the synthesized compounds have been characterized by spectral [IR, $1 \mathrm{H}$ NMR, 13C NMR] studies.

General procedure for preparing naphthoquinones derivatives

Compounds $\mathbf{1 b}, \mathbf{2 b}$ and $\mathbf{3 c}$ were achieved by cascading or domino reactions of 1,4-naphthoquinone and sodium salt of 4-sulfonate-1,2-naphthoquinone with acids methylenes and secondary amine respectively, using different methods of synthesis.

\section{4-Morpholino-1,2-naphthoquinone (1b)}

Was obtained from morpholine $(0.17 \mathrm{~g}, 1.92 \mathrm{mmol})$; red solid $(0.35 \mathrm{~g}, 80 \%)$; mp $183{ }^{\circ} \mathrm{C}$; IR: $1574,1689 \mathrm{~cm}^{-1}$; ${ }^{1} \mathrm{H}$ NMR $\left(300 \mathrm{MHz}, \mathrm{CDCl}_{3}\right) \delta(\mathrm{ppm}): 2.78(\mathrm{~m}, 4 \mathrm{H}) ; 3.03$ (m, 4H); $6.01(\mathrm{~s}, 1 \mathrm{H}) ; 7.04(\mathrm{~d}, J=7.75 \mathrm{~Hz}, 1 \mathrm{H}) ; 7.35(\mathrm{t}, J$ $=7.50 \mathrm{~Hz}, J=1.25 \mathrm{~Hz}, 1 \mathrm{H}) ; 7.43(\mathrm{t}, J=7.50 \mathrm{~Hz}, J=$ $1.25 \mathrm{~Hz}, 1 \mathrm{H}) ; 8.30(\mathrm{~d}, J=7.50 \mathrm{~Hz}, 1 \mathrm{H}) ;{ }^{13} \mathrm{C} \mathrm{NMR}(75$ $\left.\mathrm{MHz} \mathrm{CDCl}_{3}\right) \delta(\mathrm{ppm}): 49.50\left(2 \mathrm{C}_{3},\right), 67.10\left(2 \mathrm{C}_{2},\right), 107.50$ $\left(\mathrm{C}_{3}\right), 126\left(\mathrm{C}_{9}\right), 127.5\left(\mathrm{C}_{5}\right), 128.1\left(\mathrm{C}_{8}\right), 131.5\left(\mathrm{C}_{7}\right), 132.8$ $\left(\mathrm{C}_{6}\right), 136.2\left(\mathrm{C}_{10}\right), 160.6\left(\mathrm{C}_{4}\right), 178.4\left(\mathrm{C}_{2}\right), 182.6\left(\mathrm{C}_{1}\right)$.

4-(3,4-Dihydroisoquinolin-2(1H)-yl)-1,2naphthoquinone $(\mathbf{2 b})$

Was obtained from 1,2,3,4-tetrahydroisoquinoline $(0.25$ $\mathrm{g}, 1.92 \mathrm{mmol})$; red solid $(0.47 \mathrm{~g}, 85 \%)$; mp 170-172 ${ }^{\circ} \mathrm{C}$; IR: $1578,1675 \mathrm{~cm}^{-1} ;{ }^{1} \mathrm{H} \mathrm{NMR}\left(300 \mathrm{MHz}, \mathrm{CDCl}_{3}\right) \delta(\mathrm{ppm})$ : $3.15(\mathrm{~m}, 2 \mathrm{H}), 3.85(\mathrm{~m}, 2 \mathrm{H}), 4.92(\mathrm{~m}, 2 \mathrm{H}), 6.22(\mathrm{~s}, 1 \mathrm{H})$, $6.66(\mathrm{~d}, J=7.25 \mathrm{~Hz}, 1 \mathrm{H}), 6.90(\mathrm{~m}, 1 \mathrm{H}), 7.18(\mathrm{~m}, 1 \mathrm{H})$, $7.25(\mathrm{~m}, 2 \mathrm{H}), 7.31(\mathrm{~m}, 2 \mathrm{H}), 8.25(\mathrm{~d}, J=7.25 \mathrm{~Hz}, 1 \mathrm{H}) ;{ }^{13} \mathrm{C}$ NMR (75 MHz, $\left.\mathrm{CDCl}_{3}\right) \delta(\mathrm{ppm}): 29.1\left(\mathrm{C}_{7}\right.$ ) $), 52.4\left(2 \mathrm{C}_{2}, 8^{\prime}\right)$, $104.5\left(\mathrm{C}_{2}\right), 125.4\left(\mathrm{C}_{5},\right), 126.9\left(\mathrm{C}_{4}\right), 127.5\left(\mathrm{C}_{3}\right), 128.1\left(\mathrm{C}_{5}\right)$ $128.7\left(\mathrm{C}_{9}\right), 129.0\left(\mathrm{C}_{8}\right), 129.5\left(\mathrm{C}_{6}\right), 131.4\left(\mathrm{C}_{6}\right), 132.5\left(\mathrm{C}_{7}\right)$, $133.6\left(2 \mathrm{C}_{9}, 10^{\prime}\right), 137.6\left(\mathrm{C}_{10}\right), 160.6\left(\mathrm{C}_{1}\right), 178.4\left(\mathrm{C}_{3}\right), 182.6$ $\left(\mathrm{C}_{4}\right)$.

Ethyl 2-amino-5-hydroxynaphtho[1,2-b]furan-3carboxylate $(3 c)$

Was obtained from ethyl of cyanoacetate $(0.21 \mathrm{~g}, 1.92$ mmol); darken mauve solid (0.49 g, 94\%); mp 240-242 ${ }^{\circ} \mathrm{C}$; IR: $3313,1688,1618,1575,1513,1368,1300,1279 \mathrm{~cm}^{-1}$; ${ }^{1} \mathrm{H}$ NMR (300 MHz, $\left.\mathrm{CDCl}_{3}\right) \delta(\mathrm{ppm}): 1.63-1.66(3 \mathrm{H}, \mathrm{t})$, 4.53-4.58 (2H, q), $6.23(1 \mathrm{H}, \mathrm{s}), 7.42-7.46(2 \mathrm{H}, \mathrm{m}), 7.81-$ $7.89(2 \mathrm{H}, \mathrm{m}), 8.199-8.215(1 \mathrm{H}, \mathrm{d}, J=8.00 \mathrm{~Hz}) ;{ }^{13} \mathrm{C} \mathrm{NMR}$ $\left(75 \mathrm{MHz}, \mathrm{CDCl}_{3}\right) \delta(\mathrm{ppm}): 16.2,58.8,97.5,106.1,112.4$, $118.2,122.3,124.5,127.4,131.9133 .1,146.5,149.4$, $160.1,166.8$.

The products 2-chloro-3-morpholino (or 3,4dihydroisoquinolin-2(1H)-yl)-1,4-naphthoquinone (1a and 2a) and 2-amino-1,4-naphthoquinone (1c) were synthesized by the grinding method 'Grindstone Chemistry' of 2,3-dichloro-1,2-naphthoquinone, 1,4naphthoquinone with the corresponding secondary amine derivatives in Polyethylene glycol (PEG) 300 at room temperature for 5-10 mn, sodium azide in glacial acetic acid for $12 \mathrm{~h}$ in room temperature, respectively.

2-Chloro-3-morpholino-1,4-naphthoquinone (1a)

Was obtained from morpholine $(0.17 \mathrm{~g}, 1.92 \mathrm{mmol})$; red solid $(0.40 \mathrm{~g}, 76 \%)$; mp $109{ }^{\circ} \mathrm{C}$; IR: $1581,1649 \mathrm{~cm}^{-1}$; ${ }^{1} \mathrm{H}$ NMR (300 MHz, $\mathrm{CDCl}_{3}$ ) $\delta(\mathrm{ppm}): 3.62(\mathrm{t}, J=4.8 \mathrm{~Hz}$, $4 \mathrm{H}), 3.82(\mathrm{t}, \mathrm{J}=4.8 \mathrm{~Hz}, 4 \mathrm{H}), 7.68-7.73(\mathrm{~m}, 2 \mathrm{H}), 8.01(\mathrm{dd}$, $J=8.2 \mathrm{~Hz}, J=1.8 \mathrm{~Hz}, 1 \mathrm{H}), 8.11(\mathrm{dd}, J=8.2 \mathrm{~Hz}, J=1.8$ $\mathrm{Hz}, 1 \mathrm{H}) ;{ }^{13} \mathrm{C}$ NMR $\left(75 \mathrm{MHz}, \mathrm{CDCl}_{3}\right) \delta(\mathrm{ppm}): 50.1(2 \mathrm{x}$ C-N), 68.0 ( 2 x $\underline{\mathrm{C}}-\mathrm{O}), 116.1\left(\mathrm{C}_{2}\right), 126.9\left(\mathrm{C}_{8}\right), 128.6\left(\mathrm{C}_{5}\right)$, $133.1\left(\mathrm{C}_{7}, \mathrm{C}_{6}\right), 134.2\left(\mathrm{C}_{10}\right), 136.1\left(\mathrm{C}_{9}\right), 152.4\left(\mathrm{C}_{3}\right), 179.0$ $\left(\mathrm{C}_{1}\right), 182.1\left(\mathrm{C}_{4}\right)$.

2-Chloro-3-(3,4-dihydroisoquinolin-2(1H)-yl)-1,4naphthoquinone (2a)

Was obtained from 1,2,3,4-tetrahydroisoquinoline (0.255 g, $1.92 \mathrm{mmol})$; red solid $(0.55 \mathrm{~g}, 89 \%)$; mp $170{ }^{\circ} \mathrm{C}$; IR: $1578,1650 \mathrm{~cm}^{-1} ;{ }^{1} \mathrm{H}$ NMR $\left(300 \mathrm{MHz}, \mathrm{CDCl}_{3}\right) \delta(\mathrm{ppm})$ : 2.97 (t, 2H), 4.20 (t. 2H), 5.22 (s. 2H), 7.16-7.39 (m, 4H), 7.70-7.78 (m, 2H), $8.04(\mathrm{dd}, J=8.2 \mathrm{~Hz}, J=1.8 \mathrm{~Hz}, 1 \mathrm{H})$, $8.12(\mathrm{dd}, J=8.2 \mathrm{~Hz}, J=1.8 \mathrm{~Hz}, 1 \mathrm{H}) ;{ }^{13} \mathrm{C} \mathrm{NMR}(75 \mathrm{MHz}$, $\left.\mathrm{CDCl}_{3}\right) \delta(\mathrm{ppm}): 51.1\left(\mathrm{C}_{3}{ }^{\prime}\right), 50.8\left(\mathrm{C}_{4},\right), 54.8\left(\mathrm{C}_{1}\right), 115.2$ $\left(\mathrm{C}_{2},\right), 117.3\left(\mathrm{C}_{6}, \mathrm{C}_{7}\right), 124.4\left(\mathrm{C}_{5}\right), 126.5\left(\mathrm{C}_{8}\right), 128.1\left(\mathrm{C}_{8}\right)$, $128.7\left(\mathrm{C}_{5}\right), 131.1\left(\mathrm{C}_{7}, \mathrm{C}_{6}\right), 133.8\left(\mathrm{C}_{9}, \mathrm{C}_{10}\right), 134.2\left(\mathrm{C}_{9}\right.$, $\left.\mathrm{C}_{10}\right), 152.1\left(\mathrm{C}_{3}\right), 179.2\left(\mathrm{C}_{1}\right), 180.5\left(\mathrm{C}_{4}\right)$.

2-amino-1,4-naphthoquinone (1c)

Dark brown-red solid $(0.32 \mathrm{~g}, 95 \%)$; mp $202{ }^{\circ} \mathrm{C}$; IR: $3370,1685,1612,1558,1362,1270 \mathrm{~cm}^{-1}$; ${ }^{1} \mathrm{H}$ NMR $(300$ $\left.\mathrm{MHz}, \mathrm{CDCl}_{3}\right) \delta(\mathrm{ppm}): 5.10(\mathrm{~s}, 2 \mathrm{H}), 5.93(\mathrm{~s}, 1 \mathrm{H}), 7.55-$ $7.59(\mathrm{td}, J=1.2 \mathrm{~Hz}, J=1.2 \mathrm{~Hz}, 1 \mathrm{H}), 7.64-7.68(\mathrm{td}, J=$ $1.6 \mathrm{~Hz}, J=1.6 \mathrm{~Hz}, 1 \mathrm{H}), 7.98-8.02(\mathrm{t}, 2 \mathrm{H}) ;{ }^{13} \mathrm{C} \mathrm{NMR}(75$ $\left.\mathrm{MHz}, \mathrm{CDCl}_{3}\right) \delta(\mathrm{ppm}): 105.2,126.2,126.3,130.5,132.3$, 133.4, 134.6, 148.3, 181.9, 183.8.

2-[(triphenylphosphoranylidene)amino]-2Hnaphtho[2,3-d][1,2,3]triazole-4,9-dione (2c)

Was prepared by other methods in mild conditions, using the 1,4-naphthoquinone with sodium azide in ethanol in the presence of triphenylphosphine at room temperature. It was obtained from malononitrile $(0.13 \mathrm{~g}$, 
$1.92 \mathrm{mmol})$; darken mauve solid $(0.42 \mathrm{~g}, 98 \%)$; mp 260$262{ }^{\circ} \mathrm{C}$; IR: $3183,2215,1642,1565,1261 \mathrm{~cm}^{-1} ;{ }^{1} \mathrm{H}$ NMR $\left(300 \mathrm{MHz}, \mathrm{CDCl}_{3}\right) \delta(\mathrm{ppm}): 6.77(1 \mathrm{H}, \mathrm{s}), 7.308-7.349(1 \mathrm{H}$, $\mathrm{t}, J=8.00 \mathrm{~Hz} \& J=8.40 \mathrm{~Hz}), 7.520-7.560(1 \mathrm{H}, \mathrm{t}, J=$ $8.00 \mathrm{~Hz} \& J=8.00 \mathrm{~Hz}), 7.788-7.809(1 \mathrm{H}, \mathrm{d}, J=8.40 \mathrm{~Hz})$, 8.099-8.115 $(1 \mathrm{H}, \mathrm{d}, J=8.00 \mathrm{~Hz}), 8.136\left(2 \mathrm{H}_{\mathrm{NH} 2}, \mathrm{~s}\right), 10.134$ $\left(1 \mathrm{H}_{\mathrm{OH}}, \mathrm{s}\right) ;{ }^{13} \mathrm{C} \mathrm{NMR}\left(75 \mathrm{MHz}, \mathrm{CDCl}_{3}\right) \delta(\mathrm{ppm}): 62.0 ; 97.3$; $115.5 ; 117.7 ; 120.1 ; 120.6 ; 122.4 ; 123.4 ; 124.2 ; 127.4$; $134.8 ; 150.8 ; 165.7$.

5-morpholino-7,12-dihydrobenzo[a]phenazine (3b)

Was synthesized by the condensation of diamine with the corresponding 4-morpholino-1,2-naphthoquinone in refluxing ethanol in the presence of a base such as ammonium acetate for 2 hours; Light yellow $(0.21 \mathrm{~g}, 35 \%)$; mp $240^{\circ} \mathrm{C}$; IR: $3105,1595,1510 \mathrm{~cm}^{-1} ;{ }^{1} \mathrm{H}$ NMR $(300 \mathrm{MHz}$, $\left.\mathrm{CDCl}_{3}\right) \delta(\mathrm{ppm}): 2.80(\mathrm{~m}, 4 \mathrm{H}), 3.13(\mathrm{~m}, 4 \mathrm{H}), 6.81(\mathrm{~s}, 1 \mathrm{H})$, 7.02-7.27 (m, 2H), 7.29-7.85 (m, 4H), 8.27-8.35 (dd, 2H); ${ }^{13} \mathrm{C}$ NMR $\left(75 \mathrm{MHz}, \mathrm{CDCl}_{3}\right) \delta(\mathrm{ppm}): 52.10(2 \times \mathrm{C}-\mathrm{N})$, 67.2 (2 x C-O), 115.2, 126.4, 126.8, 127.1, 128.2, 129.5, $130.8,131.4,132.5,133.4,138.2,142.3,147.7,151.2$.

\subsection{Selected Test Microorganisms}

A panel of 12 well-documented pathogenic bacteria and 3 pathogenic yeasts obtained from our Laboratory: Antibiotiques Antifongiques: physico-chimie, synthèse et activité biologique, Département de biologie, Faculté des Sciences, (Tlemcen University) Algeria, was used in the this study. All examined compounds were tested against pathogenic microbes, including the bacteria: Pseudomonas aeruginosa ATCC 27853, Escherichia coli ATCC 25922, Salmonella typhimurium ATCC 13311, Acinetobacter baumanii ATCC 19606, Klebsiella pneumonia ATCC 700603, Enterobacter cloacae ATCC 13047, Citrobacter freundii ATCC 8090, Proteus mirabilis ATCC 35659 (Gram-negative bacteria), Staphylococcus aureus ATCC 25923, Bacillus cereus ATCC 10876, Enterococcus faecalis ATCC 49452, Lysteria monocytogenes ATCC 15313(Gram-positive bacteria), and the yeasts: Candida albicans ATCC 444, Candida albicans ATCC 10231, Candida albicans ATCC 26790.

\subsection{Test methods}

\subsubsection{The Disc Diffusion Method}

Screening of the antibacterial activity of the all examined compounds was assessed by agar disc diffusion method according to recommendations of National Committee for Clinical Laboratory Standards [16]. Results were compared with that of lawsone. Stock solutions of the all the examined compounds $(51.2 \mathrm{mg} / \mathrm{ml})$ were dissolved in DMSO. The cell density of the inoculum was adjusted with a UV-Visible spectrophotometer (spectronic GENESYS 2) in order to obtain a final concentration of approximately $10^{8}$ colony-forming units (optical density $\left.\mathrm{OD}_{625}=0.08-0.1\right)$. This suspension was inoculated on Mueller Hinton agar (MHA). After drying, Wattman paper discs containing $10 \mu \mathrm{l}$ of the examined compounds were applied in the Petri dish. The activity was determined by the measurement of the inhibitory zone diameter in $\mathrm{mm}$ after incubation at $37^{\circ} \mathrm{C}$ for $24 \mathrm{~h}$. Gentamicin and Ciprofloxacin were used as antibacterial references. Pure solvent was used as negative control. The antimicrobial activity was considered to start when the diameter was 6 $\mathrm{mm}$ or higher and was classified as follows: Very Strong activity: diameter $\geq 30 \mathrm{~mm}$; Strong activity: diameter between 21-29 mm; Medium activity: diameter between 16-20 mm; Weak activity: diameter between 11-15 mm; Small or no activity: diameter $\leq 10 \mathrm{~mm}$.

The antifungal activity screening was measured according to a standardized disc diffusion Method for yeasts. Amphotericin B was used as a positive control. The antifungal activity was performed as for bacteria but the culture medium used was Mueller Hinton $+2 \%$ glucose $+0.5 \mu \mathrm{g} / \mathrm{ml}$ methylene blue / $\mathrm{pH} \mathrm{7.4}$, and cell density was adjusted in order to obtain a final concentration of approximately $1-5 \quad 10^{6} \mathrm{CFU}\left(\mathrm{OD}_{530}=\right.$ $0.12-0.15)[17]$.

\subsubsection{Broth Microdilution Method}

Examined compounds were subjected to an evaluation of their level activity using the broth microdilution method to estimate the Minimal Inhibitory Concentration (MIC) according to the recommendations of CLSI [18]. A series of two-fold dilutions from 512 to $2 \mu \mathrm{g} / \mathrm{ml}$ (dissolved in DMSO up to $5 \%$ final DMSO concentration) were prepared in a 96 well-sterile microplate. In each well we introduced $100 \mu \mathrm{l}$ of the dilution compound to be tested. Subsequently, $100 \mu \mathrm{l}$ of an inoculum containing $10^{6} \mathrm{CFU}$ was added to each well. The effect of DMSO at a concentration of 5\% was checked and eliminated; at these concentrations DMSO has no apparent effect on the microbial growth. The wells used as a negative control were prepared using the inoculum alone. Gentamicin and Ciprofloxacin were used as the antibacterial reference. The microplate was incubated at $37^{\circ} \mathrm{C}$ for $24 \mathrm{~h}$. Minimal Inhibitory Concentration (MIC) was considered as the weakest concentration at which no turbidity could be observed with the naked eye.

MIC against $C$. albicans was assessed as for bacteria but the culture medium used was Roswell Park Memorial Institute (RPMI) 1640/ pH 7.0 (Roswell Park Memorial Institute medium) with glutamine and a $\mathrm{pH}$ indicator but without bicarbonate and supplemented with glucose to a final concentration of $2 \%$ (RPMI $2 \% \mathrm{G}$ ), and cell density was approximately 1-5 106 CFU [19].

All experiments were repeated three times and the results were expressed as average values.

\section{Results}

A total of 10 compounds and one methanol extract were tested against 12 bacteria and 3 yeasts. Beside the compounds $\mathbf{2 b}$ and $\mathbf{3 b}$ who showed neither antibacterial nor antifungal activities, all the tested compounds showed at least some activity against one or more tested microorganisms, even though this was sometimes only observed against one strain. The strain $P$. aeruginosa was resistant to all tested compounds.

The antibacterial properties of the compounds were determined with different strains. These bacterial strains represent important Gram-positive and Gram-negative species. Results (Table 1) reported the inhibition zones (mm) of tested compounds determined against all bacterial strains.

The antibacterial screening results indicates that compounds 1a, $\mathbf{2 a}, \mathbf{1 b}$, and $\mathbf{1 c}$ have significant inhibitory activity and compounds $\mathbf{a}, \mathbf{2 b}, \mathbf{3 b}, \mathbf{2 c}$ and $\mathbf{3 c}$ has poor activity against the majority of strains comparing to 
lawsone activity results. Compound 1c showed strong activity against $S$. typhimurium, $A$. baumanii, $C$. freundii, P. mirabilis, S. aureus and $C$. albicans $\left(\mathrm{Ca}_{1}\right.$ and $\left.\mathrm{Ca}_{2}\right)$, and moderate activity against $B$. cereus and C.albicans $\left(\mathrm{Ca}_{3}\right)$. Compounds $\mathbf{1 b}$ and $\mathbf{2 a}$ showed also strong activity against $C$. freundii, $P$. mirabilis, $S$. aureus and $B$. cereus. Compounds $\mathbf{1 b}$ and $\mathbf{2 a}$ showed also, strong activity against $S$. aureus, $C$. freundii, and $S$. aureus respectively. Lawsone showed strong activity against $B$. cereus and medium activity against $S$. typhimurium, $C$. freundii, and $S$. aureus. Compounds 1a, 2a and $\mathbf{2 c}$ showed medium activity against $A$. baumanii, S. aureus, B.cereus, and E. feacalis. The same activities were recorded with lawsone against $S$. typhimurium, $C$. freundii, and $S$. aureus. However, all the other results were weak, small or no activity against most of strains.

The antimicrobial activity of methanol extract was quantitatively assessed by the presence or absence of inhibition zone and zone diameter respectively as given in Table 1 . The effects against gram positives bacteria were more pronounced than those against the gram negatives. The disc diffusion method showed that only P. mirabilis, $S$. aureus, B. cereus, E. faecalis and L. monocytogenes were sensitive toward the methanol extract. However, no antimicrobial activity was found against the other strains.

The DMSO discs showed no inhibitory zones. Grampositive bacteria were more sensitive than Gram-negative bacteria. A total 9 products showed medium to strong activities against 6 strains of bacteria and 3 yeasts. The results are presented in Table 1.

Antifungal properties of the compounds and methanol extract were determined against three yeasts including: $C$. albicans ATCC 444, C. albicans ATCC 10231 and $C$. Albicans ATCC 26790. Results (Table 1) indicate that the compound 1c and the methanol extract showed the only interesting activity (medium to strong), and inhibition zones were ranging from 13 to $18 \mathrm{~mm}$ and 12.5 to 23.5 respectively. However, all the other compounds showed weak, small or no activity against most of the strains.

Table 1. Antimicrobial activity of synthesized compounds against test microorganisms

\begin{tabular}{|c|c|c|c|c|c|c|c|c|c|c|c|c|c|c|c|}
\hline \multirow{2}{*}{$\begin{array}{c}\text { Com } \\
\text { poun } \\
\text { ds }\end{array}$} & \multicolumn{15}{|c|}{ Inhibition zone (mm) } \\
\hline & $\mathrm{Pa} *$ & $\mathrm{Ec} *$ & $\mathrm{St} *$ & $\mathrm{Kp}^{*}$ & $\mathrm{Ab} *$ & $\mathrm{Cf} *$ & $\mathrm{Pm} *$ & En c* & $\mathrm{Sa} *$ & $\mathrm{Ef} *$ & $\mathrm{Bc} *$ & $\mathrm{Lm} *$ & $\mathrm{Ca} 1 *$ & $\mathrm{Ca} 2 *$ & $\mathrm{Ca} 3 *$ \\
\hline $\mathrm{a}$ & 6 & 8 & 6 & 6 & 6 & 6 & 6,5 & 6 & 9,5 & 10,5 & 8 & 6 & 7 & 9 & 8,5 \\
\hline a1 & 6 & 6 & 6 & 6 & 6 & 11,7 & 6 & 6 & 15 & 6 & 11,33 & 6 & 14,5 & 14,5 & 10 \\
\hline a2 & 6 & 9 & 14 & 7 & 15,5 & 25,7 & 25,5 & 6 & 23,5 & 14 & 21 & 6 & 6 & 6 & 6 \\
\hline b1 & 6 & 6 & 6 & 6 & 6 & 6 & 6 & 6 & 21,5 & 6 & 14 & 6 & 6 & 6 & 6 \\
\hline b2 & 6 & 6 & 6 & 6 & 6 & 6 & 6 & 6 & 6 & 6 & 6 & 6 & 6 & 6 & 6 \\
\hline b3 & 6 & 6 & 6 & 6 & 6 & 7 & 6 & 6 & 6 & 6 & 6 & 6 & 6 & 6 & 6 \\
\hline $\mathrm{c} 1$ & 6 & 6 & 26,5 & 8 & 27 & 22 & 28,5 & 9 & 23,5 & 10 & 18,5 & 15,25 & 23,5 & 23 & 18 \\
\hline c2 & 6 & 7 & 15 & 6 & 20,5 & 6 & 6 & 8 & 6 & 6 & 6 & 6 & 7 & 6 & 6 \\
\hline c3 & 7 & 8,5 & 8 & 6 & 10,5 & 8,5 & 8,5 & 6 & 13,5 & 10 & 10 & 6 & 10 & 11,5 & 10 \\
\hline $\mathrm{L}$ & 6 & 15 & 17 & 8 & 7 & 18 & 7 & 6 & 17,5 & 6 & 25 & 6 & 6 & 7 & 7 \\
\hline Henn & & & & & & & & & & & & & & & \\
\hline $\begin{array}{c}\mathrm{a} \\
\text { extra } \\
\mathrm{ct}\end{array}$ & 6 & 6 & 6 & 8 & 8.5 & 7.5 & 12 & 9 & 12 & 12 & 12.5 & 12.5 & 13.5 & 12.5 & 12 \\
\hline $\begin{array}{c}\text { DMS } \\
\mathrm{O}\end{array}$ & 6 & 6 & 6 & 6 & 6 & 6 & 6 & 6 & 6 & 6 & 6 & 6 & 6 & 6 & 6 \\
\hline Gent & 21,33 & 21,5 & 25 & 14 & 14,5 & 26 & 23 & 18 & 22 & 18,5 & 20 & 17 & ND & ND & ND \\
\hline $\mathrm{Cip} \dagger$ & 33 & 36 & 35,5 & 24 & 24,5 & 32,5 & 33,5 & 20 & 24,5 & 16 & 26,5 & 23 & ND & ND & ND \\
\hline $\begin{array}{l}\text { Amp } \\
\mathrm{h} \mathrm{B \dagger}\end{array}$ & ND & ND & ND & ND & ND & ND & ND & ND & ND & ND & ND & ND & 20 & 21 & 21,66 \\
\hline
\end{tabular}

Test microorganisms: Pa-Pseudomonas aeruginosa, Ec-Escherichia coli, St-Salmonella typhimurium, Kp-Klebsiella pneumoniae, Ab-Acinetobacter baumanii, Cf-Citrobacterfreundii, Pm-Proteus mirabilis, En c- Enterobacter cloacae ATCC 13047, Sa-Staphylococcus aureus, Bc-Bacillus cereus, EfEnterococcus faecalis, Lm-Lysteria monocytogenes, Ca1- Candida albicans ATCC 444, Ca2-Candida albicans ATCC10231,Ca3-Candida albicans ATCC 26790.

Bacteria tested in MHA medium, yeasts in MHA medium $+2 \%$ of glucose $+0,5 \mu$ ml of methylene bleu; ND, not determined; $\uparrow$ Standard: GentGentamicin (15 $\mu \mathrm{g} / \mathrm{disc})$; Cip-Ciprofloxacin (5 $\mu \mathrm{g} / \mathrm{disc})$, Amph B-Amphotericin B (512 $\mu \mathrm{g} / \mathrm{disc})$.

Next we investigated the MIC of the active compounds. The most interesting MICs were obtained from 1a, 2a, 1c, and 1b. Compounds a and $\mathbf{3 c}$ showed no interesting MICs against all bacteria observed at the highest test concentration of $512 \mu \mathrm{g} / \mathrm{ml}$. The results are presented in Table 2. In particular, the most promising compounds 1c and $\mathbf{1 b}$ (where the activity vary between 64 to $8 \mu \mathrm{g} / \mathrm{ml}$ ) displayed an activity 16 to 128 fold higher when compared with the corresponding parent molecule, lawsone. The other compounds showed MICs results similar or lower at least one folds comparing to MICs values of the structural analogue, lawsone.

Data for the methanol extract are presented in Table 2 as the minimal inhibitory concentration. The best MICs were obtained against the three yeasts followed by the strain Proteus mirabilis. However, methanol extract showed the same MICs $(4380 \mu \mathrm{g} / \mathrm{ml})$ against all other bacteria strains.
MICs values (Table 2) of the compounds 1a, 2a and 1c were found to display an activity 8 times higher than lawsone $(\mathrm{MIC}=64 \mu \mathrm{g} / \mathrm{ml}$ ), against the only strain $C$. albicans ATCC 26790. The methanol extract showed the same MICs as showed with pure lawsone (MIC $=512 \mu \mathrm{g} /$ $\mathrm{ml}$ ) against the tow yeasts strains.

\section{Discussion}

The search for new antimicrobial agents is an important line of research because of the resistance acquired by several pathogenic microorganisms. The prevalence of strains of $S$. aureus resistant to conventional antibiotics has increased to high levels in some hospitals [20,21]. In nosocomial, this bacterium is one of the most prevalent microorganism's worldwide [22]. In addition, currently, fungal infections are ranked fourth of nosocomial infections. The yeast $C$. albicans is implicated in more 
than $75 \%$ of invasive or systemic fungal infections [23]. In this work the activity of henna methanol extract and new substituted naphthoquinones was assessed against bacteria known to cause respiratory, gastrointestinal, skin and urinary disorders.

Quinonoid compounds, by virtue of their easy redox cycling capacity, are known to possess wide-ranging antimicrobial as well as anti-cancer features. However, the prospective antimicrobial activity of quinonoid compounds, from synthesis or isolated from natural sources, has mostly remained unexplored. The reported tuberculostatic and antimicrobial activities of $L$. inermis Linn. (henna) would indicate the probable involvement of lawsone, i.e. 2-hydroxynaphthoquinone, which is known to be the main bioactive constituent of this herb, in the antimicrobial activity $[5,8]$.

Table 2. MICs of the tested compounds and standard antibiotics against selected microorganisms

\begin{tabular}{|c|c|c|c|c|c|c|c|c|c|c|c|c|c|c|c|}
\hline & \multicolumn{15}{|c|}{$\mathrm{MIC}(\mu \mathrm{g} / \mathrm{ml})$} \\
\hline & $\mathrm{Pa} *$ & Ec* & St * & $\mathrm{Kp} *$ & $\mathrm{Ab} *$ & $\mathrm{Cf} *$ & $\mathrm{Pm} *$ & En c* & $\mathrm{Sa} *$ & Ef* & $\mathrm{Bc} *$ & $\mathrm{Lm} *$ & $\mathrm{Ca}^{*} *$ & $\mathrm{Ca} 2 *$ & $\mathrm{Ca}^{*}$ \\
\hline $\mathrm{a}$ & 1024 & 1024 & 1024 & 1024 & 1024 & 1024 & 1024 & 1024 & 256 & 512 & 256 & 1024 & 512 & 512 & 128 \\
\hline a1 & 1024 & 128 & 1024 & 1024 & 1024 & 1024 & 64 & 1024 & 512 & 1024 & 512 & 1024 & 512 & 256 & 64 \\
\hline $\mathrm{a} 2$ & 512 & 512 & 512 & 1024 & 512 & 512 & 256 & 256 & 64 & 512 & 64 & 1024 & 512 & 512 & 64 \\
\hline b1 & 512 & 256 & 16 & 1024 & 512 & 16 & 64 & 128 & 256 & 1024 & 64 & 1024 & 1024 & 1024 & 1024 \\
\hline b3 & 512 & 512 & 512 & 512 & 512 & 512 & 512 & 512 & 512 & 512 & 512 & 512 & 512 & 512 & 256 \\
\hline $\mathrm{c} 1$ & 1024 & 128 & 64 & 256 & 8 & 128 & 64 & 128 & 16 & 128 & 16 & 256 & 256 & 256 & 64 \\
\hline c3 & 1024 & 1024 & 1024 & 1024 & 1024 & 1024 & 1024 & 1024 & 128 & 1024 & 512 & 1024 & 512 & 512 & 512 \\
\hline $\mathrm{L}$ & 1024 & 1024 & 1024 & 1024 & 1024 & 1024 & 1024 & 1024 & 512 & 1024 & 512 & 1024 & 512 & 512 & 1024 \\
\hline Henna extract & 4380 & 4380 & 4380 & 4380 & 4380 & 4380 & 2190 & 4380 & 4380 & 4380 & 4380 & 4380 & 512 & 512 & 512 \\
\hline Gent $\uparrow$ & 0.5 & 0.5 & 0.25 & 8 & 8 & 0.5 & 0.5 & 0.5 & 0.5 & 16 & 0.5 & 8 & ND & ND & ND \\
\hline $\mathrm{Cip} \dagger$ & 0.25 & 0.008 & 0.008 & 0.25 & 0.5 & 0.016 & 0.008 & 0.25 & 0.25 & 0.25 & 0.064 & 0.25 & ND & ND & ND \\
\hline Amph B $†$ & ND & ND & ND & ND & ND & ND & ND & ND & ND & ND & ND & ND & 1 & 1 & 0.5 \\
\hline
\end{tabular}

Test microorganisms: Pa-Pseudomonas aeruginosa, Ec-Escherichia coli, St-Salmonella typhimurium, Kp-Klebsiella pneumoniae, Ab-Acinetobacter baumanii, Cf-Citrobacter freundii, Pm-Proteus mirabilis, En c- Enterobacter cloacae ATCC 13047, Sa-Staphylococcus aureus, Bc-Bacillus cereus, EfEnterococcus faecalis, Lm-Lysteria monocytogenes, Ca1- Candida albicans ATCC 444, Ca2- Candida albicans ATCC 10231,Ca3-Candida albicans ATCC 26790.

Standard antibiotics: Gent-Gentamycin; Cip-Ciprofloxacin, Amph B-Amphotericin B. ND—not determined.

Ethanol extracts of 20 plants species used by Yemeni traditional healers to treat infectious diseases were screened for their antibacterial activity against both gram positive and gram negative bacteria. The ethyl acetate extract of $L$. inermis was found to be the most active against all the bacteria in the test system. [24] Quinonoid compounds from henna were studied in vitro for antimicrobial properties. [25] Genotoxic studies on lawsone suggested that it was a weak bacterial mutagen for Salmonella typhimurium strain TA98 and was more clearly mutagenic for strain TA2637. Aqueous, methanol and chloroform crude extracts of leaf showed the in vitro antimicrobial activity to inhibit the growth of 6 human pathogenic fungi and 4 types of bacteria in dose dependent manner $[26,27,28]$.

During screening of barks of 30 plant species against Microsporum gypseum and Trichophyton mentagrophytes, L. inermis extract exhibited absolute toxicity. The extract showed broad fungitoxic spectrum when tested against 13 ring worm fungi. Lawsone isolated from the leaves of $L$. inermis has shown significant antifungal antibiotic effect [29]. Aqueous extract of leaves of $L$. inermis was tested for the antifungal potential against eight important species of Aspergillus that were isolated from sorghum, maize and paddy seed samples. A. flavus recorded high susceptibility and hence solvent extracts viz., petroleum ether, benzene, chloroform, methanol and ethanol extracts of the plant showed significant antifungal activity [30].

Some studies indicate that the antibacterial activity of a family of 1,4-naphthoquinones require a free keto group at position 1 and 4 and the substituent at position 2 must not be a hydroxyl group [8]. Some 1,4-naphthoquinones tested in the present study have a free keto function, and the most effective ones do not have a hydroxyl group at position 2. Lawsone, which has a hydroxyl group at this position, showed lower activity than compounds $\mathbf{1 c}$ and 1b. Indeed, $\mathbf{2 b}, \mathbf{3 b}$ and $\mathbf{3 c}$ did not cause inhibition, suggesting that the free keto function at position 1 and 4 is required for this activity.
Studies on antimicrobial activity of 1,4naphthoquinones demonstrated that those with electron releasing or weak electron-withdrawing groups at position 2 or 3 may enhance their antimicrobial activity [31]. An explanation for this behavior is related to the electronic effect of the groups directly bonded at the naphthoquinone ring. This effect is attributed to the enhancement of the hydrogen bonding, allowing stronger binding at its site of action. Thus, in our case, compounds that have free ketone reveal the most important activities.

Another study of the antimicrobial activity of 1,4naphthoquinones indicated that active compounds must possess at least a substitution at position 2 or 3 , which is either an electron-releasing or weaker electron with drawing group [32]. Consequently, the hydrogen bonding capacity is enhanced and allows the compound to bind more strongly to its site of action. Moreover, excess hydrophilicity or lipophilicity causes a loss of activity because the oil/water partition coefficient must be adequate for the activity of the compound [32].

Thus, in our case, we found that the presence of the quinone structure is essential for the activity of most active synthetic derivatives. The electrochemical behavior of different classes of quinones has been extensively reviewed [33]. In the specific case of hydroxyquinones, the possibility of stabilization of the electrogenerated anion radical by intramolecular hydrogen bonding causes a shift of the reduction potentials to less negative values $[34,35]$ a fact that in some cases can be fundamental with respect to biological activity [35]. For peroxidation in the presence of oxygen to occur, the presence of hydroxyl groups in the quinone moiety has been demonstrated to be essential.

The structure of our novel naphthoquinone analogs had a dramatic effect of their antibacterial and antifungal activity. The amino group (-NH2) in the $\mathrm{C}-2$ position seemed to be an important structural feature as 1c had stronger activity than their counterparts, Lawsone and dichlone (a) (which lack amino group in the C-2 position). 
Morpholine substituents seem playing a role in the activity showed by compounds $\mathbf{1 a}$ and $\mathbf{1 b}$ witch have 1,4/1,2 free keto function.

In addition of a hydroxy group to the C-2 position of 1,4-naphthoquinone (to form lawsone) resulted in a loss of activity, particularly noteworthy where MIC values are not below $512 \mu \mathrm{g} / \mathrm{ml}$. Dichlone (which has two chloro groups in the C-2 and C-3 position) had slightly higher activity than 1c. Comparison of antimicrobial activity of 1,2naphthoquinones with that of the 1,4-derivatives gave no consistent results. Some 1,2-derivatives (1b) were more active, while others were less (1a). Nevertheless, the carbonitrile substituent 3c showed a decrease in activity, although they present no groups at position 2. Such behavior could be explained considering that the carboxylate is a long chain directly bounded to the furan ring and cause a positive electronic effect. Furthermore, the decrease in activity observed for the $\mathbf{1 a}$ and $\mathbf{3 b}$ derivatives may be related to the presence of the hydrophilic isoquinoline substituent, since excess of hydrophobicity causes loss of activity [33].

The question therefore remains to understand the mechanism of naphthoquinone antimicrobial activity and structural requirements to express this type of activity. Electronegative substitutions order $(\mathrm{Cl} \square \mathrm{O} \square \mathrm{N} \square \mathrm{C})$ in the 2-position of 1,4-naphthoquinone decreases or abolishes antimicrobial activity.

\section{Conclusion}

In general, our results confirm earlier studies on henna extracts and naphthoquinones compounds. Activity against gram-negative and positive bacteria was noticeable. Those gram-negative bacteria tested were much more sensitive, with the compounds $1 \mathrm{c}$ and $1 \mathrm{~b}$ inhibiting $S$. typhimurium, A. baumanii and C. freundii at MIC values of $16 \mu \mathrm{g} / \mathrm{mL}$ or less. The results suggest that hydroxyl and amino substitution were associated with the antimicrobial effects of naphthoquinons, other substituents may either increase or abolish the antimicrobial activity, and effects cannot therefore presently be predicted based on structure. In considering the use of henna plant and its bioactive compounds in human medicine, the possibility of both haemolysis and nephrotoxicity of the new active compounds should be investigated at an early stage.

\section{Disclosure of Interest}

The authors declare that they have no conflicts of interest concerning this article.

\section{Acknowledgement}

The authors acknowledge Mr. Daniel Verin (USA) and Dr. Mohamed Boudjelal (UK) for proof-reading the manuscript.

\section{References}

[1] Newman, D.J., Cragg, G.M. and Snader, K.M, "The influence of natural products upon drug discovery". Nat. Prod. Rep. 17. 215234. Jun. 2000
[2] Ernst, E, "The efficacy of herbal medicine: An overview". Fundam. Clin. Pharmacol. 19. 405-409. Apr. 2005.

[3] Chaudhary, G., Goyal, S. and Poonia, P, "Lawsonia inermis Linnaeus: A Phytopharmacological”. Int. J. Pharma. Sci. Drug Res. 2(2). 91-98. Jun. 2010.

[4] Bhuvaneswari, K., Gnana, P.S., Kuruvilla, A. and Appala, R.A, "Inhibitory concentrations of Lawsonia inermis dry powder for urinary pathogens". Indian J. Pharmacol. 34. 260-3. Aug. 2002.

[5] Rahmoun, N.M., Boucherit-Otmani, Z., Boucherit, K., Benabdallah, M. and Choukchou-Braham, N. "Antifungal activity of the Algerian Lawsonia inermis (henna)," Pharm. Biol, 51(1). 131-135. Jan.2013.

[6] Villemin, D., Benabdallah, M., Rahmoun, N., Jouannic, C., Choukchou-Braham, N. and Mostefa-Kara, B, "A green route for synthesis of new 1,2-naphthoquinomethane acetonitriles in water", Synth. Commun, 40 (23). 3514-3521. Nov.2010.

[7] Chung, Y., Yoo, J., Park, S., Kim, B.H., Chen, X., Zhan, C. and Cho H, "Dependence of antitumor activity on the electrophilicity of 2-substituted 1,4-naphthoquinone derivatives", Bull. Korean Chem. Soc, 28 (4). 691-694. Apr. 2007.

[8] Rahmoun, N.M., Boucherit-Otmani, Z., Boucherit, K., Benabdallah, M., Villemin. D. and Choukchou-Braham, N, "Antibacterial and antifungal activity of lawsone and novel naphthoquinone derivatives," Med. Mal. Infec, 42 (6). 270-275. Jun. 2012.

[9] Castro, F.A.V., Mariani, D., Panek, A.D., Eleutherio, E.C.A. and Pereira, M.D, "Cytotoxicity mechanism of two naphthoquinones (menadione and plumbagin) in saccharomyces cerevisiae," plos one 3 (12). e3999. Dec. 2008.

[10] Valderrama, J.A., Leiva, H., Rodriguez, J.A., Theoduloz, C. and Schmeda-Hirshmann, G, "Studies on quinones. Part 43: Synthesis and cytotoxic evaluation of polyoxyethylenecontaining 1,4naphthoquinones," Bioorg. Med. Chem, 16 (7). 3687-3693. Apr. 2008.

[11] Pathirana, C., Jensen, P.R. and Fenical, W, "Marinone and debromomarinone: Antibiotic sesquiterpenoid naphthoquinones of a new structure class from a marine bacterium," Tetrahedron Lett, 33(50). 7663-7666. Dec.1992.

[12] Pierpont, C.G, "Unique Properties of Transition Metal Quinone Complexes of the MQ3 Series," Coord. Chem. Rev. 219-221, 415-433. Jan.2001.

[13] Plyta, Z.F., Li, T.H., Papageorgiou, V.P., Mellidis, A.S., Assimopoulou, A.N., Pitsinos, E.N. and Couladouros, E.A, "Inhibition of topoisomerase I by naphthoquinone derivatives," Bioorg. Med. Chem. Lett, 8 (23). 3385-3390. Dec. 1998.

[14] Salmon-Chemin, L., Buisine, E., Yardley, V., Kohler, S., Debreu, M.A., Landry, V., Sergheraert, C., Croft, S.L., Krauth-Siegel, R.L. and Davioud-Charvet, E, "2- and 3-substituted 1,4naphthoquinone derivatives as subversive substrates of trypanothione reductase and lipoamide dehydrogenase from Trypanosoma cruzi: synthesis and correlation between redox cycling activities and in vitro cytotoxicity," J. Med. Chem, 44 (4). 548-565. Feb. 2001.

[15] Sharma, V.K, "Tuberculostatic activity of henna (Lawsonia inemis Linn.)," Tubercle, 71 (4). 293-295. Dec. 1990.

[16] National Committee for Clinical Laboratory Standards. Performance standards for antimicrobial disk susceptibility tests, Approved standard-eight edition M2-A8, Wayne P.A, 2003.

[17] Epsinel-ingroff, A, "Standardized disk diffusion method for yeasts," Clin. Microbiol. Newsl, 29 (13). 97-100. July.2007.

[18] Clinical Laboratory Standards Institute. Methods for dilution antimicrobial susceptibility tests for bacteria that grow aerobically, Approved standard. CLSI document. M07-A8. Wayne, P.A, 2009.

[19] Clinical Laboratory Standards Institute. Reference method for broth dilution antifungal susceptibility testing of yeasts, Approved Standard- Third Edition M27-A3 Wayne P.A, 2008.

[20] Shaefler, S, "Methicillin-resistant strains of Staphylococcus aureus resistant to quinolones," J. Clin. Microbiol, 27 (2). 335-336. Feb.1989.

[21] Shalit, I., Berger, S.A., Gorea, A. and Frimerman, H, "Widespread quinolone resistance among methicillin-resistant Staphylococcus aureus isolates in a general hospital", Antimicrob. Agents Chemother, 33 (4). 181-184. Apr.1989.

[22] Emori, T.G. and Gaynes, R.P, "An overview of nosocomial infections including the role of the microbiology laboratory", Clin. Microbiol. Rev, 6 (4). 428- 442. Oct.1993.

[23] Richardson, M.D, "Changing patterns and trends in systemic fungal infections", J. Antimicrob. Chemother, 56. (S1). i5-i11. Sept. 2005. 
[24] Ali, N.A.A., Julich, W.D., Kusnick, C. and Lindequist U, "Screening of Yemeni medicinal plants for antibacterial and cytotoxic activities". J Ethnopharmacol, 74 (2). 173-179. Feb. 2001.

[25] Dama, L.B, Poul, B.N. and Jadhav, B.V, "Antimicrobial activity of Napthoquinonic compounds". J. Ecotox. Environ. Monit, 8. 213-215. 1999.

[26] Saadabi, M.A.A, "Evaluation of Lawsonia inermis L. (Sudanese Henna) Leaf extracts as an antimicrobial agent”. Res. J. Biol. Sci. 2(4). 419-423. 2007.

[27] Malekzadeh, F, "Antimicrobial activity of Lawsonia inermis L". Appl. Microbiol. 16. 663-664. 1968.

[28] Habbal, O.A., Ai-Jabri, A.A., El-Hag, A.H., Al-Mahrooqi, Z.H. and Al- Hashmi, N.A, "In-vitro antimicrobial activity of Lawsonia inermis Linn (henna) - A pilot study on the Omani henna”. Saudi Med. J. 26. 69-72. Jan. 2005.

[29] Dixit, S.N., Srivastava, H.S. and Tripathi, R.D, "Lawsone, the antifungal antibiotic from the leaves of Lawsonia inermis and some aspects of its mode of action”. Indian Phytopathol. 31. 131133. 1980.

[30] Raveesha, K.A., Satish, S., Mohana, D.C. and Raghavendra, M.P, "Antifungal activity of some plant extracts against important seed borne pathogens of Aspergillus sp”. J Agr Technol. 3(1). 109-119. May. 2007.

[31] Gershon, H. and Shanks, L, "Fungitoxicity of 1,4naphthoquinones to Candida albicans and Trichophyton mentagrophytes," Can. J. Microbiol, 21 (9). 1317-1321. Sept.1975.

[32] Gafner, S., Wolfender, J.L., Nianga, M., Stoceckli-Evans, H. and Hostettmann, K, "Antifungal and antibacterial naphthoquinones from Newbouldia leavis roots," Phytochemistry, 42 (5). 13151320. July.1996.

[33] Ferraz, P.A.L., De Abreu, F.C., Tonholo, J., Chiari, E., Pinto, A.V., Glezer, V. and Goulart, M.O.F, "Electrochemical aspects of the reduction of biologically active 2-hydroxy-3-alkyl-1,4naphthoquinones," J. Electroanal. Chem, 507. 275-286. July.2001.

[34] Ashnagar, A., Bruce, J.M., Dutton, P.L. and Prince, R.C, "Oneand two-electron reduction of hydroxy-1,4-naphthoquinones and hydroxy-9,10-anthraquinones. The role of internal hydrogen bonding and its bearing on the redox chemistry of the anthracycline antitumour quinines", Biochim. Biophys. Acta, 801 (3). 351-359. Oct. 1984.

[35] Crawford, P.W., Carlos, E., Ellegood, J.C., Cheng, C.C., Dong, Q. Liu, D.F. and Luo, Y.L, "The Electrochemistry of antineoplastic furanquinones: Electrochemical properties of benzo[b]naphtho[2,3-d]furan-6,11-dione derivatives", J. Electroanal. Chem, 41 (15). 2399-2403. Nov.1996. 